\title{
Understanding Systematic Reviews for Orphan Cancer Disorders-A Perspective
}

\author{
We Jiang*, Young Hoon Yang, Eun-Kyong Kim and Sungsoo Cho \\ University of South Korea, Onnuri, Jeonju-si, South Korea
}

Submission: July 30, 2018; Published: August 15, 2018

*Corresponding author: We Jiang, University of South Korea, Onnuri, Jeonju-si, South Korea; Email: wejiang19999@gmail.com

Keywords: Food and drugs; Oncological disorders; Clinical trials; Collaboration; Chronic illness; Disability; Premature death

\section{Opinion}

The United States Food and drugs administration defines a rare disease as any disorder that affects fewer than 200,000 Americans. The European definition is when a disease affects less than 1 in 2,000. These rare diseases poses lot of challenges in treatment decision making [1-3]. In particular Oncological disorders caused multitude of dilemma in clinical decision making. These rare cancers maybe difficult to characterize or define, the recruitment into clinical trials maybe difficult with lack of high quality evidence with very few centers with necessary expertise to manage and do research in these disorders [4-6]. Rare Oncological disorders may cause chronic illness, disability, and often premature death. They are complex with lack of adequate treatment with a very high health care spending. They have a huge tendency to get misdiagnosed or get wrongly diagnosed. Very few drug companies tend to invest into such rare diseases since it may be difficult to cover cost for developing therapeutics for such small and geographically diverse populations [7-10].

To advance medical research on rare diseases, a research network facilitates collaboration, enrollment in studies and trials, and sharing of data. National Institutes of Health (NIH) established the Rare Diseases Clinical Research Network I (RDCRN I) to cater to the needs of these rare diseases. In addition certain toxicities and therapeutics to treat certain common malignancies maybe rarely used and these don't find common utility in clinical settings [11-14]. Conducting a systematic review on rare oncological disorders, their distinctive features may help in an accurate assessment of prevalence of the condition; allow to find trends and similarities comparisons between countries; and, highlights areas of high or low prevalence [15-18]. Streamlines targeting of resources, planning and prioritization of future research. The cardinal points while doing a rare cancer systematic review is to define the research question, extraction of information appropriate screening of data, with data extraction and data synthesis. Similarities exist between SRs of prevalence of rare diseases but individual conditions present unique challenges. A good knowledge of disease classification and historical nomenclature is essential for effective searching and screening [9-10,19]. Whether diagnosis is simple or complex, it should be clearly and fully reported, data extracted and compared with other studies reporting the same outcome. Definitions of prevalence should be clearly extracted and compared to similar studies. Limitations surrounding individual studies and their effect on prevalence should be carefully considered.

\section{References}

1. https://www.nih.gov/news-events/news-releases/nih-fundsresearch-consortia-study-more-200-rare-diseases

2. Benson R, Mallick S, Prasad VB, Haresh KP, Gupta S, et al. (2015) Medullomyoblastoma treated with craniospinal radiation and adjuvant chemotherapy: Report of 4 cases and review of the literature. J Egypt Natl Cancer Inst 27(2):109-111.

3. Venkatesulu BP, Pathy S, Vallonthaiel AG, Chawla B (2015) Epithelialmyoepithelial carcinoma of lacrimal gland from an ex pleomorphic adenoma. BMJ Case Rep. 2015.

4. Mallick S, Giridhar P, Venkatesulu BP (2015) In regard to Risk of second non-breast cancer after radiotherapy for breast cancer: A systematic review and meta-analysis of 762,468 patients. Radiother Oncol 115(3): 431.

5. Yang X, Venkatesulu BP, Mahadevan LS, Aliru ML, Mackeyev Y, et al. (2018). Gold-Small Interfering RNA as Optically Responsive Nanostructures for Cancer Theranostics. J Biomed Nanotechnol 14(5): 809-828.

6. Venkatesulu BP, Mallick S, Singh A, Julka PK (2015) Non small cell carcinoma of lung with metachronous breast metastasis and cardiac tamponade: Unusual presentation of a common cancer. J Egypt Natl Cancer Inst 27(3): 165-169.

7. Venkatesulu B, Mallick S, Giridhar P, Upadhyay AD, Rath GK (2018) Pattern of care and impact of prognostic factors on the outcome of head and neck extramedullary plasmacytoma: a systematic review and individual patient data analysis of 315 cases. Eur Arch Otorhinolaryngol 275(2): 595-606 
8. Mallick S, Benson R, Venkatesulu B, Melgandi W, Rath GK (2017) Patterns of care and survival outcomes in patients with astroblastoma: an individual patient data analysis of 152 cases. Childs Nerv Syst 33(8): 1295-1302.

9. Venkatesulu BP, Mallick S, Rath GK (2017) Patterns of care of cervical cancer in the elderly: A qualitative literature review. J Geriatr Oncol 8(2): 108-116.

10. Bhanuprasad V, Mallick S, Bhasker S, Mohanti BK (2015) Pediatric head and neck squamous cell carcinoma: report of 12 cases and illustrated review of literature. Int J Pediatr Otorhinolaryngol 79(8): 1279-1282.

11. Bhasker S, Mallick S, Benson R, Bhanuprasad V, Sharma A, et al. (2017) A multimodality approach to sinonasal undifferentiated carcinoma: a single institute experience. J Laryngol Otol 131(1): 19-25.

12. Venkatesulu BP, Mallick S, Lin SH, Krishnan S (2018) A systematic review of the influence of radiation-induced lymphopenia on survival outcomes in solid tumors. Crit Rev Oncol Hematol 123: 42-51.

13. Ko K, Wang Y, Kotla S, Fujii Y, Vu HT, et al. (2018) Developing a reliable Mouse Model for cancer Therapy-induced cardiovascular Toxicity in cancer Patients and survivors. Front Cardiovasc Med 5: 26.
14. Mahadevan LS, Zhong J, Venkatesulu B, Kaur H, Bhide S, et al. (2018) Imaging predictors of treatment outcomes in rectal cancer: an overview. Crit Rev Oncol Hematol 129: 153-162.

15. Prasad VB, Mallick S, Upadhyay AD, Rath GK (2017) Systematic review and individual patient data analysis of pediatric head and neck squamous cell carcinoma: an analysis of 217 cases. Int J Pediatr Otorhinolaryngol 92: 75-81.

16. Thottian AG, Mallick S, Venkatesulu B, Kumar R, Haresh K, et al. (2017) Surviving Triple Trouble: Synchronous Breast and Cervical Cancer, HIV Infection and Myocardial Infarction. Breast J 23(6): 731-735.

17. Benson R, Giridhar P, Venkatesulu BP, Mallick S, Raza MW, et al. (2017) Re-irradiation for head and neck squamous cell carcinoma. J Egypt Nat Cancer Inst 29(1): 1-9.

18. Yusuf SW, Venkatesulu BP, Mahadevan LS, Krishnan S (2017) Radiationinduced cardiovascular disease: a clinical perspective. Front Cardiovasc Med 4: 66

19. Aliru ML, Schoenhals JE, Venkatesulu BP, Anderson CC, Barsoumian HB, et al (2018) Radiation therapy and immunotherapy: what is the optimal timing or sequencing? Immunotherapy 10(4): 299-316.
Your next submission with Juniper Publishers will reach you the below assets

- Quality Editorial service

- Swift Peer Review

- Reprints availability

- E-prints Service

- Manuscript Podcast for convenient understanding

- Global attainment for your research

- Manuscript accessibility in different formats

( Pdf, E-pub, Full Text, Audio)

- Unceasing customer service

Track the below URL for one-step submission

https://juniperpublishers.com/online-submission.php 